\title{
THE LITIGANT AND THE ABSENTEE IN FEDERAL MULTIPARTY PRACTICE
}

Procedural devices permitting multiparty litigation are designed to achieve the prompt adjudication of an entire dispute and to eliminate unnecessary and repetitive litigation. If this goal of judicial efficiency were the only concern of these techniques, the development of a workable set of federal multiparty procedures would be an easy task. The number of acceptable devices is limited, however, by the presence of another important consideration-the protection of the interests of all persons who may be affected by the outcome of the litigation. At the very least, this consideration requires that the rules of procedure insure the adequate representation of such interested persons by the actual litigants. This requirement may be derived from the basic concept of due process-that the efficient administration of justice should not be attained at the expense of the right of an interested but absent party. ${ }^{1}$ For these reasons, federal multiparty procedural devices must be designed and applied to insure protection of all parties concerned with the dispute, as well as to achieve the goal of judicial efficiency and economy.

In determining whether the interests of all parties affected by the lawsuit are adequately protected, the concerned persons may be divided into two groups: litigants and absentees. The difficulty in fashioning an appropriate set of federal multiparty procedures stems from the conflict between the interests of these two groups. The plaintifflitigant seeks complete relief as quickly as possible. If a person who is in some way interested in the litigation is absent, the plaintifflitigant still expects the court to fashion appropriate relief, without the absentee if necessary. The plaintiff-litigant also expects the court to prevent the absentee from intervening, if that will delay the proceedings by raising tangential issues. The absentee, on the other hand, expects to be permitted to join in a suit if his interests will be affected in either a legal or a practical sense. ${ }^{2}$ He also expects that

1 See, e.g., Hansberry v. Lee, 311 U.S. 32 (1940). The Restatement of Judgments describes the requirement of due process in these terms:

Due process of law means only that the interests of a person should be ade-

quately represented; where it is not reasonably possible that he should be heard in person or by one selected by him or acting on his sole account, the requirement of reasonableness, which is at the basis of the rule of due process of law, is satisfied if his interests are in fact adequately represented. RESTATEMIENT OF JUDGMENTS $\$ 86$, comment $b$ (1942).

2 Absentee's rights are affected "in a legal sense" when the absentee shares with one of the litigants a right, the extent or existence of which is the subject of the litigation. If the absentee does not share a right with one of the litigants, but does possess a right of his own which may be endangered by the litigation, his right will be affected "in a practical sense" by the litigation, e.g., where a joint tenant is sued by a creditor, all joint tenants may be affected by a forced disposition of the property. 
if he chooses not to intervene, the court will nevertheless insure that his interests are adequately represented. ${ }^{3}$

Any workable system of federal multiparty techniques must attempt to strike a balance between these competing interests. That a rigid set of rules will not yield a fair balance in every case is selfevident. Therefore, the primary task of the rules is to serve as guidelines for the trial judge to use in fashioning an equitable result in a particular case. In the federal system, the set of rules which performs this function is rules 19,24 and 23 of the Federal Rules of Civil Procedure.

By requiring the compulsory joinder of indispensable absentees, old rule 19 assured that the absentee's rights would not be impaired without his presence. ${ }^{4}$ Rule 24 permitted the absentee to intervene in litigation where he believed that his rights were at stake. ${ }^{5}$ Rule 23 provided for class actions, a device which permits many litigants to resolve their individual claims at one time. ${ }^{6}$ The rule necessarily involved a variety of litigant-absentee situations. ${ }^{\top}$ In most class actions, the absentee is spared the necessity of intervening since a litigant represents his interests. Disagreements, however, can arise between

3 The defendant-litigant will have essentially the same attitude toward the absentee as the plaintiff-litigant. In compulsory joinder cases, the defendant-litigant either might want the absentee joined in order to share the costs of settlement or he might want the absentee excluded if exclusion will result in dismissal of the suit. The second desire is not worthy of protection, however, since we are positing that the plaintiff-litigant has a legitimate cause of action. The defendant-litigant's one legitimate expectation-to have the absentee joined in order to share costs-coincides with the plaintiff-litigant's desire.

In intervention cases, the defendant-litigant, like the plaintiff-litigant, will want the absentee excluded from the proceedings. The defendant-litigant's feelings will be stronger, however, since the absentee is an actual claimant against the defendantlitigant. Nevertheless, there will be times when the absentee must be admitted despite the objections of the plaintiff- and defendant-litigants, in order to protect the absentee's legitimate interests.

The role of the defendant-litigant in class actions will be discussed in greater detail below. See text accompanying note 47 infra.

4 Subject to the provisions of Rule 23 and of subdivision (b) of this rule, persons having a joint interest shall be made parties and be joined on the same side as plaintiffs or defendants.

Fed. R. Civ. P. 19 (a), 28 U.S.C. Rule 19 (1964) (emphasis added).

5 Upon timely application anyone shall be permitted to intervene in an action:

. . (2) when the representation of the applicant's interest by existing parties is or may be inadequate and the applicant is or may be bound by a judgment in the action.

FED. R. CIV. P. 24(a), 28 U.S.C. Rule 24 (1964).

6 Defendant classes are rare and are therefore discussed only in the footnotes. See note 47 infra.

7 This Comment deals exclusively with the old spurious class action. Neither the old true or hybrid class actions were as common as the spurious. Kalven \& Rosenfeld, The Contemporary Function of the Class Suit, 8 U. CHI. L. REv. 684, 698-99 (1941), and neither of them presented litigant-absentee problems as serious as those posed by the spurious action, since the absentee was more closely connected with the class.

A class action was "spurious" within the meaning of the old rule "when the character of the right sought to be enforced for or against the class is . . . (3) several, and there is a common question of law or fact affecting the several rights and a common relief is sought." Fed. R. Civ. P. 23 (a) (3), 28 U.S.C. Rule 23 (1964). 
the litigant and the absentee over such issues as whether a litigant does adequately represent the absentee, whether the absentee should be bound by the result of the class action and whether due process has been accorded the absentee.

An ideal set of procedural rules would protect the interests of both the litigant and the absentee and at the same time be administrable and time-saving. Federal Rules of Civil Procedure 19, 24 and 23, as originally written, did not achieve these goals, and have been almost entirely rewritten. ${ }^{8}$ The old rules failed to protect adequately the interests of the litigant or the absentee. ${ }^{9}$ After discussing the weaknesses of the old rules, this Comment will explore the ways in which the new rules attempt to cure these shortcomings and will suggest solutions to those problems in the rules which require still further reform.

\section{JOINDER}

Joinder involves all cases in which a plaintiff-litigant seeks to bring an absentee into the suit. A litigant suing only a single defendant always can obtain complete relief by suing wherever jurisdiction can be obtained over him. The problem becomes more difficult when there are two or more persons who are indispensable to a resolution of the plaintiff's claim. ${ }^{10}$ If these persons do not reside in the same state, the litigant may be unable to find any forum which has jurisdiction over all the parties who are necessary for the resolution of his claim or a forum in which venue is proper. In such a case, the litigant may be unable to obtain any relief at all or, at best, may secure total relief only after suing each defendant in a forum in which the defendant is subject to service of process.

The problem presented by joinder is, therefore, two-fold. First, how do the courts determine whether an absentee is indispensable to the litigation? Second, under what circumstances can a court obtain jurisdiction over an indispensable absentee or, in the alternative, fashion some relief without him? Since the definitional problem should be

8 Rules 19 and 23 and subsections (2) and (3) of rule 24 (a) have been entirely rewritten. Only $\S($ b) of rule 24 remains entirely unchanged. See notes $14,22,37$, $38,41,56,57$ infra.

9 Old Rule 19 failed to protect the plaintiff-litigant: he could not always join an indispensable absentee in the litigation. See text accompanying notes 10-11 infra. Old rule 24 failed to protect the absentee: he could not always intervene as a matter of right, if his interests were only affected in a practical sense. See text accompanying notes 38-39 infra. The old spurious class action rule, 23(a) (3), failed to protect both the plaintiff- and defendant-litigants: the absentee was not bound by the result of the class action. See text accompanying notes 54-55 infra.

10 Two or more persons might be indispensable if 1) they are all defendants and are jointly liable to the plaintiff, e.g., all the endorsers of a note, Shields v. Barrow, 58 U.S. (17 How.) 130 (1854), or 2) at least one of them is not a defendant but is so related to the controversy that he must be present for a complete resolution of the plaintiff's claim, e.g., the owner of a patent where the suit is against a licensee for patent infringement. Independent Wireless Tel. Co. v. Radio Corp. of America, 269 U.S. 459 (1926). 
viewed differently depending upon whether the court has the power to bind an absentee outside its jurisdiction, this Comment will treat the jurisdictional problem first.

Shields $v$. Barrow ${ }^{11}$ is a classic example of the jurisdictional difficulty created by the concept of indispensable parties. In a suit to rescind a note due to him, Barrow sued Shields, the signer, and six endorsers. The Supreme Court concluded that all seven were indispensable. Unfortunately for Barrow, all seven parties did not live in the same state and the Court dismissed the action. Thus, unless Barrow could find all seven in the same jurisdiction-a highly unlikely contingency under the circumstances-he could not sue for rescission.

Although some courts managed to sidestep this harsh result by straining to avoid the conclusion that the absentee was, in fact, indispensable, ${ }^{12}$ others refused to restrict the definition of indispensability. ${ }^{13}$ With the courts following divergent views, there was little certainty as to when a person was indispensable to litigation.

The new rule has not attacked this jurisdictional problem head-on, but merely has tried to diminish the extent of the problem by relaxing the definition of indispensable parties. ${ }^{14}$ This change will not solve the problem since, regardless of which definition the courts decide to use, there still will be instances where an absentee is indispensable and must be joined in the litigation.

These jurisdictional requirements, which can defeat a litigant's cause of action, are in no way related to the merits of his claim against the absentee. It therefore seems logical to inquire whether there might be other means of safeguarding the absentee's rights, which the jurisdiction rules seek to protect, without foreclosing the litigant's cause of action. The primary purpose behind the territorial limitation on

1158 U.S. (17 How.) 130 (1854). For a criticism of Shields v. Barrow, see Reed, Compulsory Joinder of Parties in Civil Actions, 55 MICH. L. Rev. 327, 340-56 (1957).

12 See, e.g., Bourdieu v. Pacific W. Oil Co., 299 U.S. 65, 71 (1936) ; Stevens v. Loomis, 334 F.2d 775 (1st Cir. 1964); Kroese v. General Steel Castings Corp., 179 F.2d 760 (3d Cir. 1950); S. C. Johnson \& Son v. Boe, 187 F. Supp. 517, 520 (E.D. Pa. 1960); New England Mut. Life Ins. Co. v. Brandenburg, 8 F.R.D. 151, 154 (S.D.N.Y. 1948) ; Hazard, Indispensable Party-The Historical Origin of a Procedural Phantom, 61 CoLUM. L. Rev. 1254, $1287-89$ (1961); Reed, supra note 11, at 336-37.

13 See, e.g., Fouke v. Schenewerk, 197 F.2d 234 (5th Cir. 1952) ; Calcote v. Texas Pac. Coal \& Oil Co., 157 F.2d 216 (5th Cir. 1946); Sneed v. Phillips Petroleum Co., 76 F.2d 785 (5th Cir. 1935).

$14 \mathrm{~A}$ person who is subject to service of process and whose joinder will not deprive the court of jurisdiction over the subject matter of the action shall be joined as a party in the action if (1) in his absence complete relief cannot be accorded among those already parties, or (2) he claims an interest relating to the subject of the action and is so situated that the disposition of the action in his absence may (i) as a practical matter impair or impede his ability to protect that interest or (ii) leave any of the persons already parties subject to a substantial risk of incurring double, multiple, or otherwise inconsistent obligations by reason of his claimed interest.

FED. R. CIV. P. 19(a). 
the jurisdiction of federal district courts is to protect the defendant from the inconvenience, cost and possible prejudice of defending the suit in a forum distant from his residence or place of business, ${ }^{15}$ an unquestionably legitimate aim. Nonetheless, since the ultimate goal of our legal system is the complete and fair adjudication of all private claims, a method which creates less of an obstacle to the thorough administration of justice than do rigid jurisdiction requirements is necessary to protect defendants from remote litigation. When joinder of several absentees is necessary to provide a forum which is capable of rendering complete relief, jurisdictional requirements should be relaxed in order to give the court power over absentees throughout the United States. A statute implementing such an expansion of jurisdiction has been proposed by the American Law Institute. If an absentee is indispensable and without the jurisdiction of the court, the ALI-proposed statute, instead of calling for dismissal of the suit, gives the court jurisdiction over the absentee:

The district courts shall have original jurisdiction of any civil action in which the several defendants who are necessary for a just adjudication of the plaintiff's claim are not all amenable to process of any one territorial jurisdiction, and one of any two adverse parties is a citizen of a State and the other is a citizen . . . of another territorial jurisdiction. ${ }^{16}$

Under the proposal, the trial court may issue service of process "anywhere within the territorial limits of the United States and anywhere outside those territorial limits that process of the United States may reach . . . ." 17

By giving federal courts the power of nationwide service of process over "indispensable parties," the plaintiff is assured that his claim will not be dismissed because of his inability to join all parties necessary for the resolution of his claim. At the same time, such extraordinary power should be invoked only when the absentee is truly necessary.

15 See 2 J. Moore, Feneral Practice TfT 4.02[3]-[5] (2d ed. 1966) [hereinafter cited as MOORE]. Another purpose of territorial limitations on the jurisdiction of federal district courts seems to be an effort rationally to allocate business among the several district courts. A deviation from standard jurisdictional requirements in the case of multiparty litigation, for good reasons, would not seem to vitiate this objective.

A final purpose of the jurisdictional limits is an attempt to make the jurisdictional limits of the federal courts coextensive with the limits of the respective state courts. There are situations, however, where it is necessary for the jurisdiction of the federal courts to extend beyond that of the state courts. The Federal Interpleader Act is an example of such a situation. See note 69 infra. A second example is the 100 -mile rule. See Fed. R. Civ. P. 4(f). It is the position of this Comment that the type of multistate, multiparty litigation discussed herein is another situation calling for more expansive federal jurisdiction.

16 ALI Study of the Diviston of Jurisdiction Between State and Federal Courts $\$ 2341$ (a) (Official Draft Part 1, Sept. 1965) [hereinafter cited as AII]. See 3A MOORE T1 19.01-1[7].

17 Id. $\$ 2344(\mathrm{a})$. 
Therefore, the determination of when an individual is "indispensable" should be made carefully, so that parties only tangentially related to the litigation will not be required to attend. On the other hand, if this proposal is not adopted and dismissal may result because of limited jurisdiction, the determination of indispensability is all the more important.

Under old rule $19,{ }^{18}$ if an absentee shared a "joint interest" with the litigant, he was deemed indispensable to the proceedings; ${ }^{10}$ if he was indispensable and the court could not obtain jurisdiction over him, dismissal was required. ${ }^{20}$ This rule often proved to be a stumbling block to the litigant, for the dismissal of the suit could well mean the end of a valid cause of action.

The new rule tries to deal with this problem by substituting a more pliable standard for the inflexible "joint interest" test. ${ }^{21}$ The trial judge is to decide on the basis of the facts before him whether a particular absentee's interests are so related to the litigation that the suit cannot be adjudicated without affecting them. If the absentee is beyond the jurisdiction of the court, the trial judge determines that the presence of the absentee is essential and the court cannot fashion any relief without him, dismissal remains mandatory. ${ }^{22}$

It remains to be seen to what degree the new rule will differ from the old. Commentators on the new rule have remarked that it: 1) goes

18 For the text of old rule 19, see note 4 sipra.

19 In 1854, the Supreme Court set down the following often-quoted definition of a joint interest:

an interest of such a nature that a final decree cannot be made without either affecting that interest, or leaving that controversy in such a condition that its final termination may be wholly inconsistent with equity and good conscience, ....

Shields v. Barrow, 58 U.S. (17 How.) 130, 139 (1854). See, e.g., Hilton v. Atlantic Ref. Co., 327 F.2d 217 (5th Cir. 1964) (nonparticipating royalty holders are indispensable parties in a suit which could result in termination of the oil and gas lease under which such holders received payment).

20 Fed. R. Civ. P. 12(b) (7), 28 U.S.C. Rule 12 (1964). See, e.g., Shields v. Barrow, 58 U.S. (17 How.) 130 (1854); Hilton v. Atlantic Ref. Co., 327 F.2d 217 (5th Cir. 1964); Calcote v. Texas Pac. Coal \& Oil Co., 157 F.2d 216 (5th Cir. 1946); United States v. Washington Institute of Technology, Inc., 138 F.2d 25 (3d Cir. 1943); United States v. Fried, 183 F. Supp. 371 (E.D.N.Y. 1960); Campbell v. Pacific Fruit Exp. Co., 148 F. Supp. 209 (D. Idaho 1957); Photometric Prods. Corp. v. Radtke, 17 F.R.D. 103 (S.D.N.Y. 1954).

21 For the text of new rule 19 (a), see note 14 supra.

22 If a person as described in subdivision (a) (1) -(2) hereof cannot be made a party, the court shall determine whether in equity and good conscience the action should proceed among the parties before it, or should be dismissed, the absent person being thus regarded as indispensable. The factors to be considered by the court include: first, to what extent a judgment rendered in the person's absence might be prejudicial to him or those already parties; second, the extent to which, by protective provisions in the judgment, by the shaping of relief, or other measures, the prejudice can be lessened or avoided; third, whether a judgment rendered in the person's absence will be adequate; fourth, whether the plaintiff will have an adequate remedy if the action is dismissed for nonjoinder.

Fed. R. CIv. P. 19(b). 
too far in that it could be interpreted as overruling existing case law ; ${ }^{23}$ 2) does no more than codify existing indispensable party decisions; ${ }^{24}$ or 3 ) does not go far enough because the rule still revolves around the concept of an "indispensable" party. ${ }^{25}$

The abolition of the rigid "joint interest" test is a commendable beginning. At the same time, because the Advisory Committee failed to explain the role of the old case law in relation to the new rule, and because the rule continues to use the term "indispensable," the new rule may further confuse rather than clarify the area of necessary joinder. If a series of cases beginning in the nineteenth century holds that an absentee in a given situation is indispensable, does the new rule ignore these cases and allow the trial judge to decide that such an absentee is not indispensable? ${ }^{26}$

23 Fink, Indispensable Parties and the Proposed Amendment to Federal Rule 19,

74 YALE L.J. 403, 430 (1965) :

The committee completely ignores the role of precedent in determining joinder requirements. Is every joinder question under the proposed rule to be decided ad hoc? What of the cases in which the Supreme Court or other appellate courts have determined that in certain situations a given absent party is or is not indispensable? . . . . Does the proposed rule attempt to overrule prior case law? If so, on what basis of authority?

Fink feels that the courts will interpret the new rule in line with the standard laid down by the First Circuit in Stevens v. Loomis, 334 F.2d 775, 777-78 (1st Cir. 1964):

[W] think that true indispensable parties are only those whose interests could not be excluded from the terms or consequences of the judgment and leave anything, or appreciably anything, for the judgment effectively to operate upon .... In other words, if there may be a viable judgment having separable affirmative consequences with respect to parties before the court, and the inquiry is concerned solely with the inequities, in the light of the total circumstances, resulting from the inability to affect absent interested parties, then such other parties should be defined as merely necessary, not indispensable.

24 Supplemental Report of the Committee on Federal Rules of Civil Procedure of the Judicial Conference of the Ninth Circuit, 37 F.R.D. 71, 89 (1965) (statement of Professor John R. McDonough) :

[The proposed revision of rule 19] purports to rewrite Rule 19 to say on its face what the courts have said that it really means. If this is what the proposed Rule does, I think we should be for it. If the proposed Rule does not restate the substance of existing law we might be against it on that ground ....

25 Cohn, The New Federal Rules of Civil Procedure, 54 GEo. L.J. 1204, 1211 (1966) :

It is too easy for courts to use the word "indispensable" as a link to the old rule and its old formalistic concepts. Upon this ground, the bulk of conflicting precedents may be deemed applicable to the new rule, and the special classifications of old rule 19 may survive. Such an approach would certainly be inconsistent with the purpose of the change in the rule.

When the proposed revisions in the rules of civil procedure were first announced in 1964, rule 19 adopted the concept of "contingently necessary" parties. 34 F.R.D. 371,379 (1964). The reaction to the new term was very unfavorable, and the term was excluded altogether from the final proposed revisions. 39 F.R.D. 73, 88 (1965). 26 The indispensable party doctrine is not procedural. It declares substantive law and accords a substantive right to a person to be joined as a party to an action when his interests or rights may be affected by its outcome. The indispensable party doctrine is beyond the reach of, and not affected by, Rule 19 of the Federal Rules of Civil Procedure, since the Rules, as later developed, cannot "abridge, enlarge or modify any substantive right".

Provident Tradesmens Bank \& Trust Co. v. Lumbermens Mut. Cas. Co., 365 F.2d 802, 805 (3d Cir. 1966), cert. denied, 386 U.S. 940 (1967). But see 3A MOORE. T 19.01-1[4]. See Fink, supra note 23 , at 430. 
Judging from the reaction of some members of the legal profession that there was no need to revise old rule $19,{ }^{27}$ it seems probable that the profession may continue to rely on the old case law in interpreting the new rule. Although, under the new rule, the trial judge is directed to determine who is an indispensable party according to the facts of each case, with such a welter of divergent views on what constitutes an indispensable party, it is quite likely that the judge will continue to look to the old case law for guidance. If this is so, then the new rule has not made as significant a change as the draftsmen intended.

The text of the new rule is excellent, in that it calls for individual treatment of each case. Trial judges thus should ignore the old case law and consider, in each suit, what effect the absence of the absentee will have on the plaintiff's claim. If the plaintiff cannot obtain complete relief without the absentee's presence, the trial judge should require that the absentee be joined, even if this requires dismissal. Under the jurisdictional proposal here outlined, the judge should use the same criterion and issue service of process regardless of where the absentee lives. The approach of the new rules properly brings before the court those absentees necessary to the litigation, regardless of the court's jurisdictional power. The combination of the more flexible definition of indispensable parties ${ }^{28}$ plus the expanded jurisdictional power of the court which has been proposed herein places the absentee in much greater danger of being called upon to participate in litigation far from home. To protect the absentee from this danger this Comment suggests new cost-taxing provisions which will be discussed in depth below. ${ }^{29}$

A litigant-plaintiff seeking to join two or more defendants residing in different states must contend with venue, as well as jurisdiction, requirements. The present venue statute for diversity cases allows the plaintiff to bring his suit in any district where all the plaintiffs or all the defendants reside or in the district in which the

27 See, e.g., Report of the Committee on Federal Rules of Civil Procedure of the Judicial Conference of the Ninth Circuit, 36 F.R.D. 209 (1964); Supplemental Report of the Committee on Federal Rules of Civil Procedure of the Judicial Conference of the Ninth Circuit, 37 F.R.D. 71 (1965) ; Fink, sipra note 23, at 433.

28 The AII model statute defines an indispensable party in these terms:

A defendant is necessary for a just adjudication of the plaintiff's claim, within the meaning of this chapter, if complete relief cannot be accorded the plaintiff in his absence, or if it appears that, under federal law or relevant State law, an action on the claim would have to be dismissed if he could not be joined as a party. ALI \& 2341(b).

The Commentary to this section explains that the first clause encompasses "any" circumstances in which a person would be deemed 'indispensable' by any court." ALI 136. The second clause is aimed at aberrational state determinations of indispensability which fall outside the bounds of the first clause. Id. Under the ALI statute, joint and several or several tort-feasors are not necessary parties in an action against the other tort-feasor.

29 See text accompanying notes 35-36 infra. 
claim arose. ${ }^{80}$ In the situations treated by this Comment-multistate, multiparty suits-the only district which is likely to qualify under the residency requirements is the district where all the plaintiffs reside. If the jurisdiction statute proposed above is adopted, however, there is the danger that the plaintiff may be able to obtain jurisdiction over the defendant in the plaintiff's home state and subject him to the less favorable laws of that state. ${ }^{31}$ Under present law, the defendant is protected for the most part from this danger by the jurisdiction rules; under the proposal set forth in this Comment, the defendant must be protected by abolishing, in this situation, the residency test for proper venue.

The second venue test under the present statute-venue is properly laid in the district where the claim arose-fails to give the trial judge sufficient guidance to decide whether a case is properly before him. First, "where the claim arose" is a vague criterion open to several different interpretations and is particularly unhelpful in the multiparty, multistate situation; second, the statute seems to limit venue to one state, whereas there may be more than one state which has sufficient interest in the case to be proper for venue; third, where the claim arose is only one of several contacts with the controversy which should be considered in selecting the proper venue. A more precise venue statute, therefore, should be adopted, similar to that proposed by the ALI:

A civil action wherein jurisdiction is founded solely on section 2341 of this title may be brought only in a district where a substantial part of the events or omissions giving rise to the claim occurred or where a substantial part of property which is the subject of the action is situated, except that where there is no such district within the United States, the action may be brought in any district where any party resides. ${ }^{82}$

$30 \mathrm{~A}$ civil action wherein jurisdiction is founded only on diversity of citizenship may, except as otherwise provided by law, be brought only in the judicial district where all plaintiffs or all defendants reside, or in which the claim arose. 28 U.S.C.A. \$1391(a) (Supp. 1967).

31 It is true that the plaintiff can now obtain jurisdiction over the defendant in the plaintiff's state if the defendant voluntarily enters that state and is served while in the state. Plaintiff obtains jurisdiction over the defendant in this case because of a free choice made by the defendant. Under the jurisdiction statute advocated in this Comment, the defendant does not have such a choice. The need therefore arises to protect the defendant from being subjected to the laws of the plaintiff's state, where the defendant has not chosen to enter it.

32 ALI $\$ 2342(a)$. The note to this section states:

Commencement venue of original actions under $\$ 2341$ is limited by this section to those federal districts having substantial contacts with the subject of the action. Except where there is no such district (because all relevant events and property are outside the United States), venue is not authorized in terms of the parties' residence.

See 3A MOORE T 19.01-1[7] 
This proposed venue statute would not only provide a forum which would be a fair compromise for all the defendants, but would also facilitate the adjudication of the suit, since, presumably, most of the necessary witnesses would live near the forum.

The proposed venue statute would also remove most of the problems involved in selecting the proper conflict-of-laws rules to apply in a multiparty, multistate suit. In Klaxon Co. v. Stentor Electric $M f g . C o .,^{33}$ the Supreme Court held that a federal district court, sitting in a diversity case, must apply the conflict-of-laws rules of the state in which it is sitting. The contingency that most endangers the absentee under the proposed jurisdiction statute is that the plaintiff will sue the defendant in the plaintiff's state and the district court will apply that state's conflict-of-laws rule because of Klaxon. The proposed venue statute, however, requires that the action be brought in a state having sufficient contacts with the controversy. Therefore, the absentee is safe in the knowledge that only the conflict-of-laws rules of a state having sufficient contacts with the case will be employed in selecting the proper substantive law..$^{34}$

One final danger for the absentee is posed by the proposed jurisdiction rules. If the absentee is forced to defend the suit in a state other than his own, his expenses undoubtedly will be greater than if he were defending the suit at home. Under present law, the defendant can only be sued in his home state, unless the plaintiff somehow obtains jurisdiction over him in another state. Therefore, if the proposed jurisdiction statute is accepted, a further provision should be adopted to insure that the absentee's costs in defending the suit in a foreign jurisdiction will be no greater than his costs were he to defend the suit at home. Such a proposed rule might require that all the absentee's expenses in excess of what it would cost him to defend the suit in his own state be taxed to the plaintiff. ${ }^{35}$ Such costs could

33313 U.S. 487 (1941).

34 The ALI proposal advocates the suspension of the Klaxon rule in multiparty, multistate cases:

Whenever State law supplies the rule of decision on an issue, the district court may make its own determination as to which State rule of decision is applicable.

ALI $\$ 2344$ (c). See the Commentary to $\$ 2344$ (c), ALI 149-52.

Suspending the Klaxon rule for multiparty, multistate cases may engender more controversy and confusion than it resolves. As indicated above, the venue rule limits the applicable conflict-of-laws rules to those states having sufficient contacts with the controversy. Therefore, in most cases, there would be no need to suspend Klaxon. If in unusual cases the district court feels that it should not apply the conflict-of-laws rule of the state in which it is sitting, it would be easier for the district court merely to transfer the case to a more convenient forum than to suspend the Klaxon rule for all multiparty, multistate cases.

35 Taxing costs is a common feature of most trials today, although, admittedly, most of the costs taxed are trial expenses and not traveling expenses of the opposing party. It is the practice in the federal courts, however, to include in the costs taxed to one party the traveling expenses of the other party in coming to have his deposition taken if the location chosen for the deposition is unnecessarily inconvenient. See, e.g., Perry v. Edwards, 16 F.R.D. 131 (W.D. Mo. 1954); Alexander v. Oberndorf, 
include traveling expenses for both the absentee and his attorney, reasonable allowance for food and lodging and expenses incurred in bringing witnesses and experts from the defendant's home to the forum. At the same time, however, the plaintiff should receive a credit for all expenses saved by the defendant for witnesses and experts already residing in the forum state. Such a cost-taxing rule not only would protect the defendant from the expense of defending the suit in a distant forum, but also would discourage the plaintiff from bringing frivolous suits. ${ }^{36}$

\section{INTERVENTION}

Intervention differs from joinder in that the absentee wants to be included, and the litigant either opposes the absentee's presence or at least believes the absentee's presence to be unimportant to his claim. The absentee, on the other hand, desires to be included, precisely because he feels that the resolution of the litigant's claim will affect his rights. If the judgment in the suit can extinguish or impair some right of the absentee, to deny intervention is tantamount to denying him a day in court.

Old rule 24 provided two categories of intervention: compulsory and permissive. If an absentee faced the threat of being legally bound by the result of litigation and his interests were not adequately represented, he could intervene in the litigation as a matter of right. ${ }^{37}$ If the absentee could not qualify under this definition, he had to seek the court's permission to intervene. ${ }^{38}$ The major weakness in this

13 F.R.D. 137 (S.D.N.Y. 1952). The cost taxation policies proposed in this Comment could best be implemented in a congressional enactment.

The ALI proposed statute allows the trial judge to dismiss suits involving claims of less than $\$ 5000$ if absentees will be unduly burdened by traveling great distances. ALI $\S 2344(\mathrm{e})$.

36 These costs will be taxed to the plaintiff-litigant, regardless of whether he wins or loses the suit. This result is necessitated by the fact that the proposed jurisdiction statute gives the plaintiff-litigant extraordinary powers over the absentee which he does not possess under present law. As a price for using these powers, he must bear the absentee's expenses. If the plaintiff-litigant does not want to incur these expenses, he must be satisfied in suing the absentee in his own state or wherever he can obtain jurisdiction over him.

37 Upon timely application anyone shall be permitted to intervene in an action: (1) when a statute of the United States confers an unconditional right to intervene; or (2) when the representation of the applicant's interest by existing parties is or may be inadequate and the applicant is or may be bound by a judgment in the action; or (3) when the applicant is so situated as to be adversely affected by a distribution or other disposition of property which is in the custody or subject to the control or disposition of the court or an officer thereof.

Fed. R. Civ. P. 24 (a), 28 U.S.C. Rule 24 (1964). See, e.g., Atlantic Ref. Co. v. Standard Oil Co., 304 'F.2d 387 (D.C. Cir. 1962); International Mortgage \& Inv. Corp. v. Von Clemm, 301 F.2d 857 (2d Cir. 1962) ; Formulabs, Inc. v. Hartley Pen Co., 275 F.2d 52 (9th Cir. 1960); Wolpe v. Poretsky, 144 F.2d 505 (D.C. Cir. 1944). This Comment will only consider subsection (2), since subsections (1) and (3) are seldom invoked.

38 Upon timely application anyone may be permitted to intervene in an action: (1) when a statute of the United States confers a conditional right 
arrangement was similar to that which plagued old rule 19: a rigid rule, which was based on the legal rights of the absentee, failed to take into account the effect a given judgment might have on his rights in a practical sense. ${ }^{39}$

The new rule attempts to cure many of the defects in the old rule by expanding intervention as a matter of right to include those cases in which the absentee's rights will be impaired in a practical sense, but not necessarily in a legal sense; such an absentee will be permitted to intervene without regard to the inconvenience caused the other parties. ${ }^{40}$ If an absentee has an interest in a suit, but not to the extent required by rule 24 (a), he can still fall back on rule $24(\mathrm{~b}),{ }^{41}$ which permits intervention at the court's discretion. When an absentee petitions to intervene under subsection $24(\mathrm{~b})$, the court considers the convenience of the litigants above the interest of the absentee, since the absentee's rights will not be impaired by the litigation. If the trial court finds that the absentee's intervention will not unduly prejudice the litigants or delay the trial, intervention will be allowed in the interest of resolving as many claims in one suit as possible. In order to remain flexible enough to deal with varied multiparty situations, the rule wisely retained both intervention by right and permissive intervention.

With the liberalized standards for intervention by right, the absentee's interests are better protected under the new rule. It is important, however, that the rule not be interpreted in a way which overlooks the interests of the litigants. When the plaintiff brought the suit, he expected the court to resolve the controversy as quickly as possible at minimum cost; the defendant was not prepared to defend against the claims of an unexpected party. In light of these legitimate expectations, it is unjust to allow the absentee an automatic right to intervene if intervention would result in the consideration of issues tangential to the plaintiff's cause of action. In short, the absentee should be permitted to intervene without consideration of the hardship

to intervene; or (2) when an applicant's claim or defense and the main action have a question of law or fact in common. . . . In exercising its discretion the court shall consider whether the intervention will unduly delay or prejudice the adjudication of the rights of the original parties. . . .

FED. R. CIV. P. 24(b).

39 See note 2 supra. An example of this distinction in the area of intervention is where the primary beneficiary of a will is sued by a claimant of his share-a residual legatee should be allowed to intervene even though his legal rights are not at stake.

40 (a) Intervention of Right. Upon timely application anyone shall be permitted to intervene in an action: (1) when a statute of the United States confers an unconditional right to intervene; or (2) when the applicant claims an interest relating to the property or transaction which is the subject of the action and he is so situated that the disposition of the action may as a practical matter impair or impede his ability to protect that interest, unless the applicant's interest is adequately represented by existing parties.

FED. R. Crv. P. 24(a).

41 FED. R. CIv. P. 24(b), note 38 supra, remains unchanged in the new rules. The vast majority of interventions which arise under $\S(b)$ fall under subsection (2). 
thrust upon the litigants, only when he is able to demonstrate to the court that the adjudication of the plaintiff's claim will affect his rights either legally or practically. In all other cases, the trial judge should permit intervention only if the increase in the efficient administration of justice will be great and the inconvenience and prejudice to the litigants comparatively minor.

There are two other requirements in the new rule which the trial judge must consider in deciding whether to grant a motion to intervene, even when the rights of the absentee definitely will be affected by the litigation. First, the new rule retains the requirement set forth in the old rule that no absentee shall be permitted to intervene if his interests are already adequately represented. Among the factors the trial judge should consider in deciding this are whether the litigant is genuinely contesting the suit and whether he is advancing the same claims as the absentee. One of the more perplexing factors the trial judge might have to consider is the quality of the litigant's attorney. Certainly, the absentee is not "adequately represented" if the litigant has retained a poor attorney. On the other hand, the trial judge will be quite reluctant to grant an absentee's motion to intervene for the announced reason that the litigant's attorney is poor. Perhaps the only solution to this dilemma is for the trial judge not to consider the quality of the litigant's attorney unless the absentee raises the issue. If the absentee does contend that he should be allowed to intervene because the litigant's attorney is poor, then the trial judge is obliged to consider the issue. ${ }^{42}$

Instead of placing emphasis only on the issue of whether the absentee is adequately represented, the rule also should approach the question from a second front. If intervention by the absentee will not disrupt the trial, he should be allowed to intervene regardless of how well his interests are already being protected. The trial judge should consider both the disruption which will ensue if the absentee is allowed to intervene and the degree to which the absentee's rights are already being protected, when deciding upon a motion to intervene.

A second requirement in new rule 24 , also present in the old rule, is that the judge must determine, in deciding upon a motion to intervene, whether the motion is "timely." This determination depends on the facts of each case, particularly the reasons for the absentee's late appearance, the degree to which the intervention will disrupt the trial and the degree to which the absentee's interests will be affected by the outcome of the litigation. If the absentee's rights

42 In any given situation the trial judge will have to consider several additional factors depending on the facts of the particular case. The judge might consider important elements of trial strategy, such as whether key witnesses have been called by the litigant, or due process considerations, such as whether the absentee has been made aware of important developments in the trial.

The new rule has not changed the substantive standards of adequacy of representation. Peterson v. United States, 41 F.R.D. 131 (D. Minn. 1966). 
will be affected by the suit in such a way that he may be unable to vindicate them in subsequest litigation, the court should allow intervention at any time before judgment, provided that the absentee's failure to intervene earlier was not caused by his own neglect. If, on the other hand, the absentee will be able to protect his rights in a later suit, he generally should not be permitted to intervene, if his intervention will hinder or impair the adjudication of the litigants' rights. ${ }^{43}$ Such an absentee should also not be permitted to intervene, except in unusual circumstances, after the pretrial order or after any other time established in the district. ${ }^{44}$

If the trial judge decides to allow the intervention, he should grant a continuance if either litigant requests one and can prove that he will be prejudiced if a continuance is not granted. A continuance in such a situation is necessary to maintain the balance between the absentee who has received permission to intervene and the litigant who did not originally expect that the absentee would be a party to the suit. ${ }^{45}$

\section{Ceass Actions}

The two previous sections have dealt with the relationship between the litigant and the absentee in nonrepresentative litigation, that is, in suits where the litigants represented only their own interests. ${ }^{46}$ This section of the Comment deals with the more complex situation presented when either the plaintiff-litigant or the defendant-litigant is the representative of a class. For purposes of this section, the absentee is also a member of that class, but not involved in the actual litigation. The fact that the absentee and one of the litigants are now members of the same class alters the relationship between them and creates new interests and problems.

The interests of a particular litigant will vary, depending on whether he is the party opposing the class or a representative of the class. Assume, first, that the litigant is the party opposing the class.

43 See generally 4 MOORE $\lceil 24.13$.

$44 \mathrm{~A}$ general rule in each district as to when motions to intervene must be filed would better guide attorneys and thereby expedite litigation.

45 Some courts have held that "intervention in an in personam action under a discretionary right must be supported by independent grounds of jurisdiction, except when the action is a class action." Beard-Ianey, Inc. v. Pressley, 18 F.R.D. 162, 163 (W.D.S.C. 1955). See, e.g., Hamilton v. Civillico, 34 F.R.D. 1 (E.D. Pa. 1963); Glover v. McFaddin, 99 F. Supp. 385 (E.D. Tex. 1951) ; Glen Falls Ins. Co. v. Cook Bros., Inc., 23 F.R.D. 269 (S.D. Ind. 1959) (dictum); 4 MOORE $\pi 24.18$ [1], at 136-37. Certainly in the case of class actions and of intervention as of right, there seem to be strong reasons for not requiring the intervening parties to satisfy independent grounds of jurisdiction. However, it seems that with regard to permissive intervention, failure to insist on the same jurisdictional requirements which would have been applicable had the intervenor participated in the suit originally would permit circumvention of the jurisdictional rules.

46 This is not to say that joinder and intervention cannot arise in the context of a class action, but only that a consideration of these techniques does not include analysis of representational interests, except to the extent that an absentee cannot intervene if his interests are already adequately represented by a litigant. 
The class action device benefits the litigant-defendant ${ }^{47}$ opposing the class, in that he is able to defend against all claims in only one suit. Therefore, he wants all the members of the class, whether actually before the court or not, to be bound by the result of the litigation, so that the judgment in the case will be res judicata for any subsequent claims. Of course, this statement of the interests of the litigant is based on a situation where the class the litigant is opposing is closely united and clearly defined and has but one cause of action against him. If the class consists of a loosely organized collection of similar, but not entirely identical, interests, the class action device is advantageous only for the resolution of common issues, but not of total claims; it may result in the resolution of all issues for various subclasses, but not for the class as a whole. In each case the court must decide whether the class action device is best suited for the particular suit or only for part of it, bearing in mind such factors as the size and composition of the class, its cohesiveness, the unity of its interests and the nature of the litigant's defenses.

On the other side of the suit, the litigant representing the class, although enjoying a different relationship with the absentee, will also want him bound by the result of the litigation. The litigant-plaintiff who is a member of the class will want the absentee to contribute to the costs of bringing the suit. ${ }^{48}$ The most effective means to encourage this contribution is to make the absentee aware, from the outset, that he will be bound by the result. ${ }^{48}$

As a general rule, then, both the plaintiff-litigant and the defendant-litigant want the absentee class member bound by the result of the class action. The old spurious class action, ${ }^{50}$ however, was a classic example of an absentee's having his cake and eating it too. Each member of the class had a similar but separate cause of action. ${ }^{51}$

47 Because the vast majority of class actions involve plaintiff classes, the textual discussion in this Comment will be limited to this factual hypothesis. One of the few common defendant classes is the unincorporated association. See, e.g., Tunstall v. Brotherhood of Locomotive Firemen, 148 F.2d 403 (4th Cir. 1945).

If the litigant opposing the class is the plaintiff, he will want all members of the class, regardless of whether they are actual parties, to be bound so that he will only have to sue once to obtain complete relief on all his claims against the class.

48 In the uncommon situation where the litigant member of the class is a defendant, see note 47 supra, he will want the absentees to be bound so that they will have to contribute to the judgment if the class loses.

49 If the class wins, the litigant may well recoup all his expenses if enough absentees intervene after judgment and contribute to the litigation costs. If the class loses, however, the litigant will have to bear all the expenses himself, since no absentees will intervene after judgment. Binding the absentees from the outset should protect the litigant from this precarious financial position-presumably more absentees will intervene before judgment and contribute to the expenses in order to ensure the best possible prosecution of the suit, since they will be bound by the judgment in any case.

50 For the text of old rule 23 (a) (3), see note 7 supra. Again, this Comment deals solely with the old spurious class action and the discussion does not pertain to either the old true or hybrid class actions.

513 MOORE II 23.10[1], at 3443; see FED. R. CIV. P. 23; Advisory Committee Note, 39 F.R.D. 69, 98-107 (1966) [hereinafter cited as Advisory Committee Note]. 
Therefore, an absentee who was not an active litigant in the suit could not be bound by the result of the class action, since his cause of action was not identical to the claims of class representatives. ${ }^{52}$ If the class won, however, some courts allowed the absentees to take advantage of the favorable judgment. ${ }^{53}$ Thus the absentee never lost. Even if he were not permitted to share in a favorable judgment, he had taken no risk and now possessed a definite settlement advantage over the defendant-litigant. Both the opposing litigant and the class representative litigant were the losers. ${ }^{54}$

It is apparent that the interests of the absentee are quite different from those of either litigant--the absentee wants to be included in the judgment if the class wins, but not to be bound by the result if the class loses. If he is allowed to choose in this fashion, the balance of interests is tipped in his favor, at the expense of both the class representative litigant and the litigant opposing the class. ${ }^{55}$ Yet, this was precisely the state of the law under the old spurious class action.

There are two other possible solutions. First, the class action rule could dictate that the absentee not be affected by the judgment, regardless of whether the class wins or loses. However, this solution would undermine the purpose behind the class action; the device would degenerate into nothing more than a suit between the single litigant and the particular members of the class bringing the suit. If only those members of a class who are actually before the court are to be bound, then there is no point in using the device, for all members of the class will eventually have to appear in court.

A more realistic solution is to bind the absentee to the result of the litigation, regardless of the outcome. As has been seen, this solution would be most favorable to the litigants, but might well be less attractive to the absentee. Our legal system does not usually compel individuals to bring suits, and this, in effect, is what would happen if the courts were to bind all absentees to the result of class actions in which they did not actively participate. To meet this objection,

62 E.g., P. W. Husserl, Inc. v. Newman, 25 F.R.D. 264 (S.D.N.Y. 1960); Kaeppler v. James H. Matthews \& Co., 180 F. Supp. 691 (E.D. Pa. 1960); see 2 W. Barron \& A. Holtzhoff, FEderaI Practice and Procedure \$ 572 (rev. ed. 1961); F. JAMES, Crvil Procedure \$ 10.18, at 497 (1965); 3 Moore $\llbracket 23.11$ [3], at 3465-68.

53 See Union Carbide \& Carbon Corp. v. Nisley, 300 F.2d 561, 589 (10th Cir. 1961), cert. denied, 371 U.S. 801 (1963); Dickinson v. Burnham, 197 F.2d 973 (2d Cir.), cert. denied, 344 U.S. 875 (1952); System Fed'n No. 91, Ry. Employees Dep't v. Reed, 180 F.2d 991 (6th Cir. 1950) ; York v. Guaranty Trust Co., 143 F.2d 503 (2d Cir. 1944), rev'd on other grounds, 326 U.S. 99 (1945); P. W. Husserl, Inc. v. Newman, 25 F.R.D. 264 (S.D.N.Y. 1960); Wilson v. City of Paducah, 100 F. Supp. 116 (W.D. Ky. 1951). See generally Advisory Committee Note 98-107.

54 If the absentee is required to contribute to the class representative's costs in bringing the suit as a condition for intervening after judgment, the hardship on the class representative litigants is, of course, less severe. Nevertheless, if the absentee knows he will be able to intervene after judgment if the class wins, there is no incentive for him to join the suit before that time, and consequently the class representative litigants may have trouble arousing enough interest initially to bring the suit. 55 For a divergent viewpoint, see Kalven \& Rosenfeld, supra note 7, at 691-95. 
the courts should allow an absentee to remove himself from the class action if he can present adequate justification for such exclusion. If he cannot, he should be bound by the result.

The draftsmen of new rule 23 have adopted a middle course between old rule 23 and the proposal made above. In a class action brought under new rule $23,{ }^{56}$ all absentees will be notified of the class action and, if they do not request to be excluded from the suit, will be bound by the result whether favorable or not. ${ }^{57}$ This better protects

56 (a) Prerequisites to a Class Action. One or more members of a class may sue or be sued as representative parties on behalf of all only if (1) the class is so numerous that joinder of all members is impracticable, (2) there are questions of law or fact common to the class, (3) the claims or defenses of the representative parties are typical of the claims or defenses of the class, and (4) the representative parties will fairly and adequately protect the interests of the class.

(b) Class Actions Maintainable. An action may be maintained as a class action if the prerequisites of subdivision (a) are satisfied, and in addition:

(1) the prosecution of separate actions by or against individual mem-

bers of the class would create a risk of

(A) inconsistent or varying adjudications with respect to individual members of the class which would establish incompatible standards of conduct for the party opposing the class, or

(B) adjudications with respect to individual members of the class which would as a practical matter be dispositive of the interests of the other members not parties to the adjudications or substantially impair or impede their ability to protect their interests; or

(2) the party opposing the class has acted or refused to act on grounds generally applicable to the class, thereby making appropriate final injunctive relief or corresponding declaratory relief with respect to the class as a whole; or

(3) the court finds that the questions of law or fact common to the members of the class predominate over any questions affecting only individual members, and that a class action is superior to other available methods for the fair and efficient adjudication of the controversy. The matters pertinent to the findings include: (A) the interest of members of the class in individually controlling the prosecution or defense of separate actions; (B) the extent and nature of any litigation concerning the controversy already commenced by or against members of the class; (C) the desirability or undesirability of concentrating the litigation of the claims in the particular forum; (D) the difficulties likely to be encountered in the management of a class action.

Fen. R. CIv. P. 23.

Cases decided under the new rule thus far have failed to develop any definite

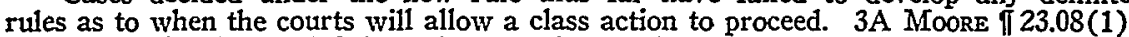
(Supp. 1967). More definite rules may be developed soon; the Second Circuit has held that a decision by a district court rejecting a class action is a final and appealable order. Eisen v. Carlisle \& Jacquelin, 370 F.2d 119 (2d Cir. 1966), cert. denied, 386 U.S. 1035 (1967).

57 [(c)] (2) In any class action maintained under subdivision (b) (3), the court shall direct to the members of the class the best notice practicable under the circumstances, including individual notice to all members who can be identified through reasonable effort. The notice shall advise each member that (A) the court will exclude him from the class if he so requests by a specified date; (B) the judgment, whether favorable or not, will include all members who do not request exclusion; and (C) any nember who does not request exclusion may, if he desires, enter an appearance through his counsel.

Id. See, e.g., Eisen v. Carlisle \& Jacquelin, 41 F.R.D. 147 (S.D.N.Y. 1966). 
the interests of the litigants, since all claims will now be resolved in one litigation, unless the absentee affirmatively seeks exclusion. The litigant is still not entirely protected, however, since the absentee will automatically be dismissed from the judgment if he merely requests exclusion. Once again the Advisory Committee's revisions have moved in the right direction, but not far enough. As indicated above, a better rule would require the absentee to present valid reasons to the court why his claim should not be adjudicated along with the similar claims of the other members of the class. The major reason the absentee might advance is that he is opposed in principle to litigating this cause of action. ${ }^{58}$ The court might also excuse the absentee if he can indicate to the court that the class action could better be handled in subclasses. The court must decide in each case whether the absentee should be excluded, weighing in the balance the nature of the absentee's objection and the disruption which will ensue if this particular absentee is excused. ${ }^{59}$

There are some absentee objections which the trial judge should be able to remedy with an appropriate procedural adjustment, short of exclusion. For instance, if the judge finds that the absentee's objection centers on inadequate representation, he should allow more members of the class to intervene. If the absentee's complaint is the high cost of travel to the location of the trial, the trial judge might tax the class representative the difference in cost for the absentee between contesting the suit in his own state and contesting it in the forum state. ${ }^{60}$ If the class is extremely large and unwieldy, the trial judge might consider dividing it into two or three smaller classes and transferring the subclasses to the appropriate forum. ${ }^{\text {B1 }}$ A major disadvantage to this solution is, of course, the threat of inconsistent results in different forums. Finally, if there is a major disagreement among members of the class which does not become apparent until all members are notified of the class action, the judge may decide at

58 It is quite conceivable that a member of a class might not consider it equitable or prudent to sue a particular litigant. If such is the case, that absentee should be excused. At the same time, however, he should be estopped from later bringing his own suit, simply because he changed his mind. If exclusion is granted for this reason, the court should have the absentee's reason for seeking exclusion inserted in the record, and the litigant opposing the class should be allowed to raise this request as an estoppel in a subsequent suit by the absentee. The plaintiff would, of course, have the burden of explaining his reasons for bringing the suit at that time.

If the absentee seeks exclusion, not because he is opposed to the suit, but because he objects to the location of the trial, the timing, the pleadings or some other alleged defect in the proceedings thus far, the trial judge is faced with a balancing task. In deciding whether to allow the absentee's request for exclusion, the judge must consider the merits of the absentee's contentions, as opposed to the disadvantage to the litigants if the absentee is excused.

59 If the class is composed of defendants, the court should be very hesitant to excuse an absentee who might be liable for a share of the judgment if the class loses.

60 If a defendant class is involved, the litigant opposing the class should be taxed. This is analogous to the rule proposed for joinder. See text accompanying notes 35-36 supra.

61 See note 82 infra. 
that time that a class action is not the proper device or that subclasses are appropriate.

Perhaps the authors of the new rule did not go further because they had already incorporated a revolutionary innovation when they purported to bind absentees who did not seek exclusion. Admittedly, under the new rule any absentee who does not want to be included in the class action can ask to be excluded. Nevertheless, the new rule does grant the district courts jurisdiction over the absentee: he is bound by the judgment uniess he seeks to be excluded. ${ }^{62}$

The question arises from where the courts derive this power to bind absentees outside their jurisdiction. Regulation of the jurisdiction of the federal courts is vested by the Constitution in Congress; ${ }^{63}$ Congress, therefore, can expand the jurisdiction of the district courts by an appropriate statute, so long as the increase in the courts' jurisdiction does not offend the due process clause or any other provision of the Constitution. ${ }^{64}$ In the case of the above amendment to rule 23 , however, the Supreme Court has increased the jurisdiction of the federal courts over absentees in class actions by amending a rule of civil

62 Neither old nor new rule 23 expressly deals with the question of diversity jurisdiction. Decisions interpreting old rule 23 held that in spurious class actions there must be complete diversity between the class representatives and the party opposing the class. See, e.g., Fitzgerald v. Dillon, 92 F. Supp. 681 (E.D.N.Y. 1950); Zelley v. Muehleck, 10 F.R.D. 62 (E.D. Pa. 1950). Each class representative was also required to satisfy the jurisdictional amount. See, e.g., Hackner v. Guaranty Trust Co., 117 F.2d 95 (2d Cir. 1941); Goldberg v. Whittier Corp., 111 F. Supp. 382 (E.D. Mich. 1953) ; Schuman v. Little Bay Constr. Co., 110 F. Supp. 903 (S.D. N.Y. 1953); Gullo v. Veterans' Co-op. Housing Ass'n, 13 F.R.D. 11 (D.D.C. 1952); Giesecke v. Denver Tramway Corp., 81 F. Supp. 957 (D. Del. 1949); 3 Moore II23.10(3) [1], at 3443. This rule developed because the claim of each class member in a spurious class action was considered to be separate, see note 52 supra, and therefore there had to be complete diversity between each class representative and the party opposing the class. Strawbridge v. Curtiss, 7 U.S. (3 Cranch) 267 (1805).

The new rule has abolished the distinctions between the classes, but has not resolved the independent grounds of jurisdiction problem. Undoubtedly, this again was left for the courts to decide. It is suggested that the requirement for complete diversity with regard to the class representatives should be preserved. However, since all class members will now be bound if they do not request exclusion, it seems that the financial requirement for federal diversity jurisdiction is satisfied if the claims of all the class members not requesting exclusion total at least $\$ 10,000$, for this class under the new rules approximates the "true" class under the old rules. See Simeone, Procedural Problems of Class Suits, 60 MICE. L. REv. 905 (1962); Blume, Jurisdictional Amount in Representative Suits, 15 MrNN. L. Rev. 501, 502 (1931):

The general test for permitting the use of representative suits and for allowing aggregation of interests for purposes of jurisdiction being apparently identical, the conclusion would seem to follow that whenever a representative suit is properly employed the value of the interests of the plaintiffs as a group should be deemed the amount in dispute rather than the value of the separate interests of the individual plaintiffs.

See 3A MOORE โI 19.01-1[7].

43 "The judicial Power of the United States, shall be vested in one supreme Court, and in such inferior Courts as the Congress may from time to time ordain and establish." U.S. CoNSr. art. III, $\$ 1 ; 2$ MOORE f 4.02[3], at 951

64 Caulfield v. United States Dep't of Agriculture, 293 F.2d 217, 219 (1961), cert. denied, 369 U.S. 858 (1962); Peterson v. Sears, 238 F. Supp. 12, 13 (N.D. Iowa 1964); Flohr v. United States, 160 F. Supp. 745, 746 (N.D.N.Y. 1957); Trauss v. City of Philadelphia, $159 \mathrm{~F}$. Supp. 672, 674-75 (E.D. Pa. 1958); Moses Taylor Lodge 95 v. Delaware, L. \& W.R.R., 39 F. Supp. 456, 457 (M.D. Pa. 1941); Seligman's, Inc. v. United States, 30 F. Supp. 895, 900 (W.D. La. 1939). 
procedure, ${ }^{65}$ and it is not clear that Congress has given the Court the power to do this.

Section 2072 of the Judicial Code, which lodges the rule-making power in the Supreme Court, states that the rules of civil procedure "shall not abridge, enlarge or modify any substantive right." ${ }^{6}$ In seeming accord with this proviso, rule 82 states that "these rules shall not be construed to extend or limit the jurisdiction of the United States district courts or the venue of actions therein." It therefore seems clear that only Congressional enactments, and not the federal rules, may extend the jurisdiction of the federal courts. It is true, of course, that the Supreme Court has increased the jurisdiction of the district courts by amending rule 4.67 No court has questioned the legality of these amendments; it is difficult to imagine one doing so. Likewise, it is probable that no court will question the amendment to rule 23. Nevertheless, the fact still remains that the amendment to rule 23 rests on questionable statutory foundations. ${ }^{68}$

In the past, Congress usually has increased the jurisdiction of the courts by passing a specific statute. ${ }^{69}$ To remove all doubt on the question, Congress should pass a Federal Class Actions Act specifically granting the district courts nationwide service of process in such suits.

The jurisdiction question is especially acute under the proposal made by this Comment, since all absentees who do not show good cause for exclusion will be bound by the judgment in the class action. However, the conception of an involuntary plaintiff is certainly not novel, ${ }^{70}$ and, since the plaintiff-absentee will be forced to litigate in the

65 The Supreme Court shall have the power to prescribe, by general rules, the forms of process, writs, pleadings, and motions, and the practice and procedure of the district courts of the United States in civil actions. . . .

Such rules shall not abridge, enlarge or modify any substantive right

- $\dot{A}$ il laws in conflict with such rules shall be of no further force or effect after such rules have taken effect....

28 U.S.C. $\$ 2072$ (1964).

${ }^{6 B} I d$.

67 See the amendments to rule 4 which became effective July 1, 1963. Rule 4(e) allows a federal court to obtain jurisdiction over a person residing outside the state, if a long-arm statute of the state in which the district court is located would give a state court jurisdiction over that person. Rule $4(\mathrm{f})$ adopts a rule allowing for service of process over persons residing within 100 miles of the location of the trial, regardless of the state in which they reside.

68 Under the old true class action, it was assumed that all members of the class were bound by the result of the class action. It must also be assumed that a court handing down a decision in a true class action had jurisdiction over those members of the class residing outside the court's jurisdiction. The extent of the court's jurisdiction in a true class action has never been challenged, primarily because most members of a true class will reside within the same state. Therefore, it never has been affirmatively stated from where the courts derived their jurisdictional powers to bind all members of a true class regardless of their residency.

69 See, e.g., 28 U.S.C. \& 2361 (1964), granting the district courts nationwide service of process for all interpleader actions falling under 28 U.S.C. $\$ 1335$ (1964).

${ }^{70}$ FED. R. CIV. P. 19(a) contains provisions for making an unwilling absentee an involuntary plaintiff: "If ... [an indispensable party] has not been so joined, the court shall order that he be made a party. If he should join as a plaintiff but refuses to do so, he may be made a defendant, or, in a proper case, an involuntary plaintiff." See also Federal Interpleader Act, 28 U.S.C. $\$ 1335$ (1964). 
class action only to the extent that he has an interest in common with other members of the class, it seems entirely appropriate to give the class action forum jurisdiction over him, so long as steps are taken to lessen the inconvenience to him. Such steps have already been suggested-the trial judge should have the power to implement subclasses ${ }^{71}$ and to tax costs. ${ }^{72}$

In the examination of multistate compulsory joinder cases, it was necessary to propose new venue rules in order to protect the absentee. ${ }^{73}$ The same need exists with multistate class actions, and the same rules should be applied. Venue in a multistate class action is properly laid only in a state having sufficient contacts with the act or omission which led to the class action, or in a state in which a major portion of the property which is the subject of the class action is located.

The district court will continue to apply the conflict-of-laws rules of the state in which it is sitting, as required by Klaxon. ${ }^{74}$ The proposed venue statute, however, requires that the action be brought in a state having sufficient contacts with the controversy. Therefore, only the conflict-of-laws rules of a state having sufficient contacts with the case will be employed in selecting the proper substantive law. ${ }^{75}$

Granting the district courts jurisdiction over the absentee does not resolve the question of when they should exercise that jurisdiction. As indicated in a previous section, ${ }^{76}$ there are important interests of both the litigants and the court which are best served by binding the absentee. Therefore, it would seem proper to include the absentee in the litigation if the interests of the other parties are thereby enhanced to a greater degree than the interests of the absentee are jeopardized.

Even after it is decided that the absentee should be included in the litigation, he still should not be bound by the result of the litigation, unless his rights are protected during the litigation to the extent that they would be if he were actually litigating himself. Before any party can be bound by the result of a suit, the due process requirements of adequate notice must be met. The new rule requires that "the best notice practicable under the circumstances, including individual notice to all members who can be identified through reasonable effort," be com-

71 If one-third of the class members reside on the east coast and two-thirds on the west coast, the trial judge should be disposed to split the class, unless the defendant is willing to make concessions (such as assuming some travel costs) to ease the burden on the distant absentees or unless the trial judge himself can devise a more feasible alternative. For instance, the nearby absentees might be able adequately to represent the cross-country absentees so that extensive travel costs are not necessary.

72 If a class member whose share of the total claim is small initiates the suit, he certainly should not be able thereby to bind distant absentees with large shares unless he is willing to assume the costs entailed by his choice of a forum.

73 See text accompanying note 32 supra.

74 See text accompanying note 33 supra.

75 See note 34 supra and accompanying text.

76 See text accompanying notes 2-3 supra. 
municated to all absentees. ${ }^{77}$ Since the absentee's interests are being adjudicated as if he were present, "the best notice practicable" would seem to require personal notice in most cases. In some cases, however, the number of absentees might be very large and their individual claims small. In such a case, the court might decide that some type of limited personal notice ${ }^{78}$ or publication ${ }^{79}$ is appropriate. If the court does decide that publication is the only practical solution, the publication should be made with sufficient notoriety to apprise the absentee of the class action. In cases where the names and addresses of all the members of a fairly large class are not known by the class representatives, the court should adopt the rule of Mullane v. Central Hanover Bank \& Trust $\mathrm{Co}^{80}{ }^{80}$ as a starting point.

After receiving notice of the class action, the absentee might move to be excluded from the suit. The trial judge should dismiss any absentee who can show good cause why he should not be included in the judgment. ${ }^{81}$ The absentee should also be excused if he can demonstrate to the court that the suit could better be handled in subclasses. ${ }^{82}$ If the absentee does not succeed in either of these arguments, the trial judge should include him in his determination of the composition of the class. ${ }^{83}$

77 FED. R. Crv. P. 23(c) (2).

78 For example, a nonregistered mimeographed letter might be sent to all members of the class.

79 This type of notice should only be resorted to in those cases where the class is large, the individual claims of the various members are small and the addresses of the members are not known.

80339 U.S. 306 (1950). Notice must be sent to all members of the class whose names and addresses can be discovered with due diligence. For those members of the class whose names and addresses cannot be discovered, publication is sufficient. Id. at 317-18.

81 See notes 58-59 supra and accompanying text.

82 FED. R. CIV. P. 23(c) (4) (B) states: "a class may be divided into subclasses and each subclass treated as a class, and the provisions of this rule shall then be construed and applied accordingly." To implement the suggestions proposed in this Comment, this section should be interpreted to mean that the trial judge will have the authority, as a condition to excusing the absentee who proves that the class action could best be handled in subclasses, to require that the absentee actually bring a class action in another jurisdiction before he is excused altogether. If this section will not bear this interpretation, then this situation should fall under the purview of the federal venue transfer statute, 28 U.S.C. $\$ 1404$ (a) (1964) :

For the convenience of parties and witnesses, in the interest of justice, a district court may transfer any civil action to any other district or division where it might have been brought.

These subsidiary class actions can only be brought in districts which could have exerted jurisdiction over the defendant the class is suing. Hoffman v. Blaski, 363 U.S. 335 (1960).

83 The judgment in an action maintained as a class action under subdivision (b) (1) or (b) (2), whether or not favorable to the class, shall include and describe those whom the court finds to be members of the class. The judgment in an action maintained as a class action under subdivision (b) (3), whether or not favorable to the class, shall include and specify or describe those to whom the notice provided in subdivision (c) (2) was directed, and who have not requested exclusion, and whom the court finds to be members of the class. Fed. R. CIv. P. 23(c) (3). See Brennan v. Midwestern United Life Ins. Co., 259 F. Supp. 673 (N.D. Ind. 1966). 
After the absentee has been included in the class, the court must continue to protect his rights. First, the court must insure that the class representatives adequately protect the interests of all absentees who will be bound by the result. Adequate representation is a difficult problem which cannot be resolved according to a percentage formula. ${ }^{84}$ Moreover, the courts are not always able to ascertain whether the class representatives standing before them adequately represent the absentees, since they are often unaware of the interests of the individual absentees. The first few cases decided under the new rule have taken an initial step toward solving this problem, placing the burden upon the litigant representing the class to prove to the satisfaction of the trial judge that he will adequately represent the absentees. ${ }^{85}$

An additional safeguard to insure that the absentee is adequately protected is the provision in the new rule permitting all absentees to make an appearance through their own counsel. ${ }^{86}$ It is questionable whether the inclusion of this right is necessary or wise. Allowing all absentees to intervene as a matter of right could hopelessly clutter the class action with too many parties. A preferred middle course would require an absentee seeking to intervene to prove that the litigant does not, in fact, adequately represent his interests, or, if the litigant does adequately represent the absentee, that the absentee's intervention will not disrupt the trial. There is little reason why different standards of intervention should exist under rules 23 and $24(\mathrm{a}) .^{87}$ It therefore is suggested that this provision be deleted from rule 23 , thus allowing rule 24 (a) to govern intervention by absentee class members. Nevertheless, the court still has an obligation to protect the interests of those absentees who cannot present sufficient reasons to justify intervention. The court must insure that such an absentee remains adequately represented and that his interests are thoroughly litigated. ${ }^{88}$ The new rule contains provisions requiring notice to absentees during the trial of

84 For cases indicating the problem of determining whether the absentees are adequately represented, see Hansberry v. Lee, 311 U.S. 32 (1940); Ford Motor Co. v. Bisanz Bros., 249 F.2d 22 (8th Cir. 1957); Knowles v. War Damage Corp., 171 F.2d 15 (D.C. Cir. 1948); Weeks v. Bareco Oil Co., 125 F.2d 84 (7th Cir. 1941); Pelelas v. Caterpillar Tractor Co., 113 F.2d 629 (7th Cir. 1940); S. C. Johnson \& Son v. Boe, 187 F. Supp. 517 (E.D. Pa. 1960). See also 3 MOoRE I23.07[4], at 3430-33.

85 Eisen v. Carlisle \& Jacquelin, 41 F.R.D. 147 (S.D.N.Y. 1966); Brennan v. Midwestern United Life Ins. Co., 259 F. Supp. 673 (N.D. Ind. 1966). The courts are concerned about large and unwieldy classes. See School District v. Harper \& Row Publishers, Inc., 267 F. Supp. 1001 (E.D. Pa. 1967); Siegel v. Chicken Delight, Inc., 271 F. Supp. 722 (N.D. Cal. 1967).

86 FED. R. CIV. P. 23(c) (2) (C). This provision probably was added with an eye toward the due process requirements.

87 See notes $42-43$ supra and accompanying text.

88 As a general rule, individuals are required to look out for their own interests, and there is no affirmative duty on the part of the courts to protect those interests during the trial. If, however, in the interest of preventing the litigation from becoming cluttered, intervention is not granted as of right, there should be a corresponding duty on the courts to make sure that all those who will be bound by the judgment are protected. 
significant developments of which they should be apprised, as well as other procedural powers designed to protect all parties involved. ${ }^{89}$ If at any time the absentee demonstrates to the court that he no longer is being adequately represented, he should be permitted to intervene.

If the absentee is forced to intervene to protect his interests, his expenses in excess of what it would cost him to litigate the same issue in his own state might be taxed to the class representative. The realization that he might have to assume some of the absentee's expenses should encourage the litigant to protect the absentee's interests during the litigation.

\section{Conclusion}

Multiparty procedures are complex both because of the number of parties involved and because of the endless variety of different relationships presented. As a consequence of this complexity, rigid rules governing the use of multiparty devices break down when called upon to deal with varying situations. Rigidity was the major flaw in the old rules and consequently one of the prime reasons behind the revisions of those rules.

In rewriting Federal Rules 19, 23 and 24, the Advisory Committee has gone far toward adopting a model system of multiparty procedures which adequately protects the interests of both the litigant and the absentee and at the same time is easily administrable by the courts. Nevertheless, the Advisory Committee has not gone far enough, perhaps because they felt reform in several steps would be more readily accepted than an immediate overhaul of the rules.

In the area of joinder, the committee did away with the inflexible "joint interest" test for determining when an absentee is indispensable, but this change does not solve the problem completely, for if an absentee is declared indispensable the action must be dismissed. A far better approach would enable the litigant to join all essential absentees with the proviso that he assume their additional costs.

Of the three areas of reform, the changes in intervention came closest to the proposals of this Comment. Under the new rule, an absentee's interests are protected in a practical as well as a legal

so In the conduct of actions to which this rule applies, the court may make appropriate orders: (1) determining the course of proceedings or prescribing measures to prevent undue repetition or complication in the presentation of evidence or argument; (2) requiring, for the protection of the members of the class or otherwise for the fair conduct of the action, that notice be given in such manner as the court may direct to some or all of the members of any step in the action, or of the proposed extent of the judgment, or of the opportunity of members to signify whether they consider the representation fair and adequate, to intervene and present claims or defenses, or otherwise to come into the action; (3) imposing conditions on the representative parties or on intervenors; (4) requiring that the pleadings be amended to eliminate therefrom allegations as to representation of absent persons, and that the action proceed accordingly; (5) dealing with similar procedural matters.

FED. R. Crv. P. 23(d). 
sense. The major advantage in the new rule and in old rule 24(b) is the flexibility to deal with varied fact situations.

In revising the rules for class actions, the Advisory Committee adopted the right course in seeking to bind all absentees to the result of the class suit. Nevertheless, further changes still must be made. First, an absentee only should be allowed to obtain exclusion from the suit upon a showing of good cause. Second, before bringing the suit the class representatives must indicate to the satisfaction of the court that they will adequately represent the interests of the absentees. With the addition of this safeguard, absentees no longer need the additional protection of intervention at will. Third, if the absentee must intervene to protect his rights, the courts should consider taxing his traveling costs to the class representatives.

The suggestions made above are premised on the assumption that, if at all possible, a controversy should be resolved in one suit. In the past, rules of jurisdiction, venue and procedure designed to protect the rights of the absentee have hindered this goal. Although the purposes behind such rules are legitimate, nevertheless, it is possible to protect the interests of the absentee without drastic consequences for the litigant's cause of action. Until these suggestions are adopted, the scales of justice will continue to come down in favor of the absentee at the expense of both the litigants and the courts. 